Василь Школяренко, кандидат технічних наук, старший науковий співробітник ORCID ID 0000-0001-8274-2231

Іван Рудніцький, кандидат технічних наук, старший науковий співробітник

ORCID ID 0000-0002-6304-3863 Національний університет оборони України імені Івана Черняховського DOI 10.33099/2617-1775/2019-01/246-256

\title{
ІНТЕРАКТИВНІ ТЕХНОЛОГІЇ НАВЧАННЯ ЯК ЗАСІБ ПІДВИЩЕННЯ ЕФЕКТИВНОСТІ КУРСОВОЇ ПІДГОТОВКИ НАЦІОНАЛЬНОГО ПЕРСОНАЛУ
}

Стаття присвячена дослідженню стану розробленості проблематики методичного забезпечення набуття військово-службових компетентностей національного персоналу Збройних Сил України до участі в міжнародних операціях з підтримання миру $і$ безпеки на основі впровадження інтерактивних технологій навчання у курсову підготовку. Сформовані вимоги до підготовки викладача при застосуванні інтерактивних технологій при організації та проведенні основних видів навчальних занять, включаючи програмні засоби Google Forms ma Kahoot. Запропоновані рекомендації щуодо застосування навчальних вправ інтерактивних технологій навчання на прикладі використання передових розробок та рекомендацій English as Medium of Instruction Оксфордського університету.

Ключові слова: види занять; інтерактивні технології навчання; інтерактивні прийоми; компетентність; курсова підготовка; національний персонал.

Постановка проблеми. 3 огляду на інтеграцію України до міжнародних організацій у сфері безпеки, зміну підходів до врегулювання воєнних конфліктів сучасності, постійну участь України у миротворчих місіях особливого значення набуває проблема набуття готовності національного персоналу Збройних Сил України (ЗС України) до участі в міжнародних операціях з підтримання миру і безпеки (МОПМБ) [1]. Окремим етапом в набутті готовності військовослужбовців до участі в МОПМБ є курсова підготовка, особливостями проведення якої є:

включення іiі до складу державної системи вищої освіти, в основу якої покладено компетентісний підхід [2; 3];

науково-методичне забезпечення освітнього процесу здійснюється на підставі інтеграції вимог директив та стандартів Департаменту миротворчих операцій ООН, Стратегічного Командування НАТО 3 трансформації, нормативних актів Міністерства освіти i науки України та Міністерства оборони України з урахуванням науково-педагогічних досягнень у галузі вищої освіти та підготовки військових фахівців [3; 4; 5];

інтеграція фахової, психолого-педагогічної та іншомовно-комунікативної видів підготовки [6]. Навчання здійснюється англійською мовою.

Проте, розвиток ряду зовнішніх та внутрішніх чинників вимагає періодичного перегляду навчальних програм курсової підготовки.

Найбільш важливими з чинників у зовнішній сфері є: 
вплив деструктивних тенденцій у сфері міжнародної безпеки, що приводить до росту воєнних конфліктів та їх ускладнення;

перехід до багатовимірних операцій та "розумної миротворчості ООН" за рахунок імплементації ініціативи “Дії з підтримки миру” (А4Р) [7];

криза ефективності діяльності міжнародних організацій у сфері безпеки.

У внутрішній сфері стримуючими чинниками $\epsilon$ :

зміна парадигми вищої військової освіти;

повільність впровадження інноваційних технологій навчання.

Все це вимагає пошуку та впровадження нових підходів щодо підвищення якості курсової підготовки військовослужбовців національного персоналу до участі в МОПМБ.

Аналіз останніх досліджень і публікацій. Загальні питання підготовки військовослужбовців 3С України до участі в МОПМБ знайшли відображення у дослідженнях Козинця I., Куропатника I., Речича С., Хацановського В., Голопатюка Л., Школяренка В., Оліфірова О., Войтеха О. та ін.

Концептуальні основи інтерактивних технологій навчання представлені у монографіях Вербицького А., Сисоєвої С., Пометун О., подальший їх розвиток у вищій військовій школі отримали у працях Вітченко А., Осьодло В., Салкуцана С. [8; 9] та ін.

Особливості застосування окремих елементів інтерактивних технологій навчання у практиці розвитку комунікативної компетентності офіцерів багатонаціональних штабів під час військово-професійної підготовки до участі в МОПМБ наведені у Шалигіної Н. [10].

Однак, проблему впровадження інтерактивних технологій у практику курсової підготовки національного персоналу досліджено не достатньо.

Виділення невирішених раніше пунктів та елементів загальної проблеми, яким присвячусться зазначена стаття. Робота спрямована на обгрунтування впровадження інтерактивних технологій навчання в курсову підготовку національного персоналу до участі в МОПМБ.

Метою статті $\epsilon$ розроблення методичних рекомендацій до проведення практичних занять 3 дисциплін курсової підготовки національного персоналу 3 використанням інтерактивних технологій навчання.

Методи досліджень. Для досягнення мети та вирішення поставлених завдань було використано систему теоретичних методів дослідження: аналіз, синтез, узагальнення та систематизація.

Виклад основного матеріалу. Курсова підготовка національного персоналу до участі в МОПМБ - це освітня діяльність, яка скерована на формування професійно-військових компетентностей, що забезпечують успішне виконання мандату місії.

Загальні вимоги до якостей випускників курсової підготовки національного персоналу подаються у вигляді переліку набутих компетентностей: соціально-особистісних, інструментальних, загальнопрофесійних та спеціалізовано-професійних. 
Аналіз основних тенденцій розвитку освіти у світі показує рух у бік інноваційної, розвиваючої, інтенсивної, індивідуально-орієнтованої стратегії освіти. Цим вимогам відповідають інтерактивні методи навчання, які базуються на наступних принципах [11, с. 37]: принцип діалогічної взаємодії, принцип кооперації й співробітництва, принцип активно-рольової (ігрової) і тренінгової організації навчання.

Суть інтерактивних методів навчання полягає в тому, що відбувається постійна активна взаємодія всіх слухачів. Викладач і слухач $є$ рівноправними суб'єктами навчання, при цьому викладач виступає як організатор процесу навчання, консультант.

Проведення занять курсової підготовки іноземними, переважно англійською, мовами ставить зовсім інші вимоги до підготовки та проведення занять як для викладачів, так $\mathrm{i}$ для слухачів. Логічно припустити, що підвищення якості підготовки із використанням англійської мови повинно враховувати та найповніше імплементувати передові розробки та рекомендації провідних університетів світу та професорів у галузі освіти англійською мовою для слухачів з країн, в яких ця мова не $\epsilon$ рідною. В першу чергу, це розробки Оксфордського університету. Вони об'єднані під загальною назвою ЕMI English as Medium of Instruction (англійська мова як середовище для викладання) та основані на застосуванні інтерактивних підходів у викладанні. Їх суть можна пояснити наступним чином [12].

Аксіоматично, основною метою викладання $є$ досягнення необхідного рівня засвоєння знань слухачем. Процес викладання умовно складається із двох взаємопов'язаних етапів: передачі інформації слухачеві та змістовного засвоєння цієї інформації. Традиційний підхід до викладання передбачає саме такий порядок вивчення: передача інформації йде першою, а вивчення другим. У новітніх інтерактивних підходах цей порядок стараються змінити, адже основним із цих етапів $є$ саме другий - це змістовне засвоєння, яке забирає більше часу та ресурсів слухачів, а отже і має бути постійно у головному фокусі роботи викладача.

Як це реалізується на практиці? Для цього слухачам надається більше часу для самостійного вивчення тематичних матеріалів, а на заняттях в групах 3 викладачем шляхом спілкування опрацьовується їх глибоке засвоєння. Забезпечується принцип “поки говорю - вивчаю”. Це є потужним інструментом, особливо коли мова йде про спілкування нерідною мовою. Крім того, під час активної підготовки до заняття слухачі шляхом ознайомлення із предметними матеріалами, які їм було рекомендовано для вивчення, мають змогу засвоїти зміст нових термінів, тоді коли в ході заняття вони повинні почути та розпізнати ці терміни для себе, а в ідеалі попрактикуватися у їх усному використанні.

Роль викладача при цьому кардинально змінюється - він перетворюється по суті на професійного задавача питань. Зрозуміло, що такий підхід вимагає від викладача повного та глибокого володіння навчальним матеріалом. Крім того, підхід до планування навчання передбачає зміни усієї концепції 
підготовки навчальних занять. Якщо у традиційному підході при підготовці заняття викладач описує у першій змістовній колонці навчальні питання та їх короткий зміст, а у другій колонці - методичні прийоми та методичні вказівки щодо відпрацювання кожного з питань, то в EMI в першій колонці описуються дії слухачів, а у другій колонці - дії викладача. Тобто при розробці заняття основний фокус зміщується на опис того, що будуть робити детально по хвилинам слухачі: відповідати на запитання, обговорювати в малих групах, слухати пояснення, виробляти рекомендації. Таким чином, інтерактивність досягається шляхом збільшення часу активної роботи (обдумування та спілкування) слухачів. При цьому виділяють два показники: час голосової роботи викладача (TTT - teacher's talking time) та час голосової роботи слухача (LTT - leaner's talking time). Необхідно зауважити, що у традиційних лекціях (читанні лекцій) ТTT наближається до 100\%, тоді як LTT близький до нуля. В EMI ці показники приблизно рівні. Викладач при цьому тільки сприяє кращому засвоєнню навчального матеріалу слухачами при їх активній роботі.

Складність та характер кожної окремої дисципліни (більш технічна чи більш гуманітарна) будуть також впливати на значення цих показників. В окремих випадках пояснення викладачем складних фактів має передувати самостійному вивченню і потребуватиме більше часу на роз'яснення. Разом 3 тим, основний фокус - як зробити засвоєння навчального матеріалу слухачем при його активній роботі - зберігається. При такому підході викладач не повинен доводити увесь навчальний матеріал (та й не матиме достатньо часу на це). Він повинен тільки встановити певні рамки цього матеріалу та домогтися від слухачів більше думати та більше висловлювати свою думку. При цьому він може використовувати різні методичні прийоми. Зрозуміло, що в ЕМІ слухачі мають змогу самостійно опановувати матеріал читаючи. В класі вони будуть мати змогу себе почути. Це є важливим елементом засвоєння, коли навчання проходить на нерідній мові. Крім того, важливо створити атмосферу для кожного слухача, щоб він мав змогу якомога довше активно працювати на занятті, при цьому не доводити до крайньої точки, коли матеріал уже не сприймається. Тому, надаючи час та можливість прочитати певну частину навчальних матеріалів до заняття, можна вивільнити час для слухачів, щоб вони слухали, тобто не перевантажувати слухачів одночасним читанням та слуханням в ході заняття.

Перехід від традиційних форм викладання навчального матеріалу до інтерактивної форми потребує зміну парадигми викладання та теоретичну i практичну підготовку викладачів до цього. При цьому останнє може проходити у формі мікро-викладання у викладацьких колективах. Для цього достатньо організувати 15 хвилинні мікро-сесії для кожного викладача, де вони матимуть змогу попрактикуватися у проведенні інтерактивного заняття, а потім решта викладацького колективу зможе це обговорити та надати певні поради стосовно посилення інтерактивності. Кожну мікро-сесію певного викладача товаришівикладачі, які поділені на три групи повинні оцінювати за наступними групами показників: 1-а група - інтерактивність, 2-а група - мова (лексика та граматика) 
i 3-я - презентаційні навички викладача. У першій групі система показників оцінки якості інтерактивності може включати: загальний рівень інтерактивності, частоту, діапазон та доцільність заданих викладачем запитань, організація та інструкції класу, ТTT та LTT. Для другої групи показниками якості мови викладання можуть служити використання тематичної термінології, ясність мови, доступність термінології, наявність логічних зв'язок між частинами лекції. Показники оцінки у третій групі включають: мова тіла та жести, постава, якості невербальної комунікації тощо. Після кожного мікровикладання викладачі у групах обговорюють результати у своїх групах та вибирають одного представника у кожній групі. Для підтримання дружньої атмосфери під час обговорень кожен коментар краще починати та закінчувати позитивними відгуками, тоді як недоліки ліпше зазначати в середині виступу.

Зміст основних видів навчальних занять при застосуванні інтерактивних технологій, на прикладі Академії оборони Збройних Сил Великої Британії (Королівський коледж оборонних наук), приведено в табл. 1.

Таблиця 1 - Проведення основних видів навчальних занять із застосуванням інтерактивних технологій

\begin{tabular}{|c|c|}
\hline \multicolumn{2}{|c|}{$\begin{array}{l}\text { Західні підходи, на прикладі Академії оборони Збройних Сил Великої Британії } \\
\text { (Королівський коледж оборонних наук) та американських військових коледжів }\end{array}$} \\
\hline Горядок підготовки та проведення занять & \\
\hline \multicolumn{2}{|l|}{ Лекція / панель } \\
\hline $\begin{array}{l}\text { Слухачі повинні приходити на } \\
\text { ознайомленими із тематикою, для цього мають } \\
\text { вивчити рекомендовану літературу, перелік якої } \\
\text { доводиться заздалегідь. Джерела інформації } \\
\text { класифікуються як обов’язкові для вивчення, так і } \\
\text { рекомендовані. Половина часу на лекції відводиться } \\
\text { на сесію запитань та відповідей. Запитання наводять } \\
\text { на критичне мислення та є викликом для лектора. } \\
\text { Для проведення лекції часто запрошують особу, яка } \\
\text { постійно досліджує зазначену тематику. Панель } \\
\text { відрізняється від лекції тим, що для доповіді } \\
\text { залучається більш ніж одна особа. }\end{array}$ & $\begin{array}{l}\text { Викладач має змогу } \\
\text { перейти від загальних понять до } \\
\text { глибоких актуально важливих } \\
\text { питань за тематикою з численними } \\
\text { прикладами. Лекція } \quad \text { носить } \\
\text { iнтерактивний характер: слухачів } \\
\text { стимулює задати складне питання, } \\
\text { лектору - навести відповідні } \\
\text { приклади. Результат мотивує до } \\
\text { подальшого переопрацювання } \\
\text { лекції внаслідок складних }\end{array}$ \\
\hline \multicolumn{2}{|l|}{ Семінап } \\
\hline $\begin{array}{l}\text { Завдання та джерела інформації видаються завчасно. } \\
\text { Керівник семінару та його учасники готуються до } \\
\text { обговорення усіх питань, а визначені слухачі } \\
\text { письмово оформлюють (до 2-х сторінок) коротку } \\
\text { відповідь на запитання, роздають їі учасникам та усно } \\
\text { доповідають щодо поставленого запитання (до } 15 \\
\text { хвилин). Решта слухачів включається у дискусію, яку } \\
\text { направляє керівник, який надає слово, перефразовує } \\
\text { запитання, активно залучає усіх слухачів до дискусії. } \\
\text { В кінці обговорення кожного запитання надається } \\
\text { слово слухачу-доповідачу, який резюмує дискусію. } \\
\text { Часто практикується семінари під керівництвом } \\
\text { слухача за присутності викладача. }\end{array}$ & $\begin{array}{l}\text { Основною метою семінару } \\
\text { активізація критичного мислення у } \\
\text { членів семінарської групи, пошук } \\
\text { нових ідей, які далі розвиваються } \\
\text { за цією тематикою, створення } \\
\text { доброзичливої } \\
\text { атмосфери, яка стимулює до } \\
\text { розвитку лідерських якостей. } \\
\text { Семінар } \\
\text { самоудосконалення інструментом } \\
\text { удосконалення викладача, } \\
\text { мислення, критичного } \\
\text { поглиблення } \\
\text { досліджень. }\end{array}$ \\
\hline
\end{tabular}


Письмові роботи мають форму есе та дисертації, носять академічний характер, який вимагає вивчення та цитування значної кількості різних джерел інформації (в середньому 3-4 посилання на сторінку тексту). Теми есе формулюються як проблемні питання, які не були розкриті в ході вивчення теми. Тема дисертації $є$ особистим вибором слухача, який повинен іï сформулювати разом із синопсисом, відповідно до чого йому буде надано керівника. Роботи здаються у визначені терміни до електронної системи, яка автоматично визначає відсоток співпадінь із існуючими джерелами. Прикладом такої електронної системи є програма Turnitin.
Основна мета есе та дисертації розвиток аналітичних здібностей, критичного мислення та творчості у слухача. Перевірка письмових робіт $є$ значним викликом i для викладача, який розвиває свої здібності до критичного оцінювання та стимулює до самостійного поглибленого вивчення проблемних питань. Такий творчий підхід безпосередньо дає хід розвитку теорії i практики у зазначених питаннях.
Для проведення стратегічний ігор (КШН) розробляється відповідний сценарій, який містить стратегічний (оперативний) фон, план проведення заходу, план нарощування обстановки. При цьому ігри та КШН є багатосторонніми, з багатьма країнами та міжнародними органами та організаціями як акторами, що найбільш повно відповідає сучасним реаліям глобалізованого суспільства. Для стратегічних ігор на 99\% береться існуюча воєннополітична та воєнно-стратегічна обстановка, замовляються найсвіжіші інформаційно-аналітичні матеріали, де розкриті стан та прогнози розвитку ситуації в залучених країнах. Для прикладу замовляються на оплатній основі матеріали, які готує The Economist Intelligence Unit. Слухачі працюють на рівні РНБО чи уряду, приймають відповідні стратегічні рішення.

Вивчення кейсів

Для організації Case study слухачам надаються оригінальні архівні документи, які не тільки описують стан речей, які склалися на момент прийняття великих історичних рішень, але і самі пропозиції, які готувалися різними органами державного та військового управління, перед їх прийняттям. Приклади Case study - рішення щодо Палестини у 20-х роках та В'єтнаму у $50-\mathrm{x}$ роках минулого століття. Після самостійного ознайомлення iз матеріалами протягом 2-х навчальних днів слухачі грають різні ролі на рівні відповідних органів управління (урядів), виробляючи свої пропозиції для прийняття рішень.

\section{Навчальний тур}

Навчальні національний та закордонні тури $\epsilon$ квінтесенцією навчання у коледжі. Підготовка до них починається задовго до їх початку. Крім організаційних та адміністративних питань, які
Case study $є$ потужною формою не тільки вивчення історичних фактів, a, в першу чергу, критичного оцінювання якості прийнятих рішень на високому рівні із сучасних позицій та із застосуванням передових методик оцінки обстановки та прийняття рішень. Case study є інструментом пізнавальної та аналітичної роботи. 


\begin{tabular}{|c|c|}
\hline $\begin{array}{l}\text { залишаються за кадром і } є \text { прерогативою } \\
\text { адміністрації коледжу у кооперації із численними } \\
\text { міністерствами, відомствами, організаціями, } \\
\text { посольствами, значна робота покладена і на слухачів. } \\
\text { Вони повинні провести самостійні дослідження та } \\
\text { досконало вивчити закріплені за ними стратегічні } \\
\text { питання стосовно політичних, економічних, } \\
\text { військових, соціальних та інших аспектів } \\
\text { функціонування визначених регіонів, країн тощо. }\end{array}$ & 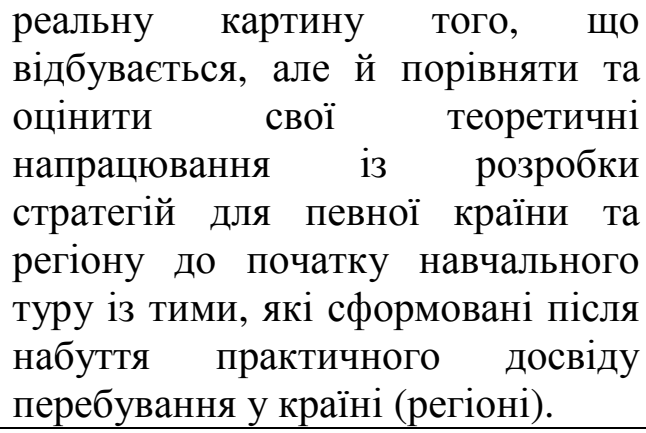 \\
\hline \multicolumn{2}{|c|}{ Робочі ланчі з керівним складом закладу та експертами, перерви на каву } \\
\hline 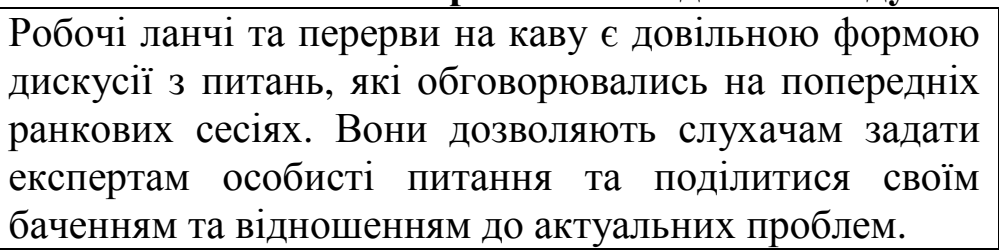 & $\begin{array}{l}\text { Робочі ланчі та перерви на каву } \\
\text { стимулюють критичне мислення у } \\
\text { слухачів, експертів та керівників, а } \\
\text { також навчають дипломатичним }\end{array}$ \\
\hline
\end{tabular}

Активізації навчально-пізнавальної діяльності слухачів сприяє застосування методичних прийомів EMI, частина яких наведено в табл. 2. Для швидкого створення інтерактивних тестових завдань, які можна виконувати як при підготовці слухачів до занять, так і в ході проведення заняття, використовуються програмні засоби Google Forms [13] та Kahoot [14].

Таблиця 2 - Приклад методичних прийомів забезпечення інтерактивності навчального процесу в іншомовному середовищі

\begin{tabular}{|c|c|}
\hline Навчальні цілі & Методичні прийоми \\
\hline \multirow[t]{9}{*}{ Згадування попереднього завдання } & 3-х ключових слів попередньої лекції (далі - ПЛ) \\
\hline & Назви попередньої теми лекції \\
\hline & Змісту ПЛ за 20 секунд в парах \\
\hline & $\begin{array}{l}\text { Змісту ПЛ за } 3 \text { хвилини з перекладом на рідну } \\
\text { мову }\end{array}$ \\
\hline & Твіт - зміст ПЛ через серію твітів \\
\hline & $\begin{array}{l}\text { Вільний запис змісту ПЛ в групах за визначений } \\
\text { інтервал часу }\end{array}$ \\
\hline & Що було нового в ПЛ? \\
\hline & Передбачити зміст наступної лекції \\
\hline & Що зроблено для між ПЛ та поточною? \\
\hline \multirow[t]{4}{*}{ Підготовка до поточної лекції/класу } & Попереднє вивчення ключових термінів \\
\hline & Розповсюдження план-конспекту лекції \\
\hline & $\begin{array}{l}\text { Попереднє } \\
\text { прочитання/попередній перегляд. }\end{array}$ \\
\hline & Вислати слухачам простий тест \\
\hline \multirow[t]{6}{*}{$\begin{array}{l}\text { Управління увагою/взаємодією протягом } \\
\text { лекцій/класів (перерване вивчення) }\end{array}$} & $\begin{array}{l}\text { Попередні 5-6 запитань до 15-20 хвилин лекції } 3 \\
\text { порівнянням відповідей }\end{array}$ \\
\hline & $\begin{array}{l}\text { Метод заміток для перших } 20 \text { хвилин лекції } \\
\text { а) незакінчені замітки - заповнити; } \\
\text { б) навмисні помилки - виправити; } \\
\text { с) графічна структура - завершити }\end{array}$ \\
\hline & Слайди із червоною зіркою-важливий зміст \\
\hline & Реконструкція лекції у парах \\
\hline & Висновки з перекладом на рідну мову \\
\hline & Голосування щодо ключових питань \\
\hline
\end{tabular}




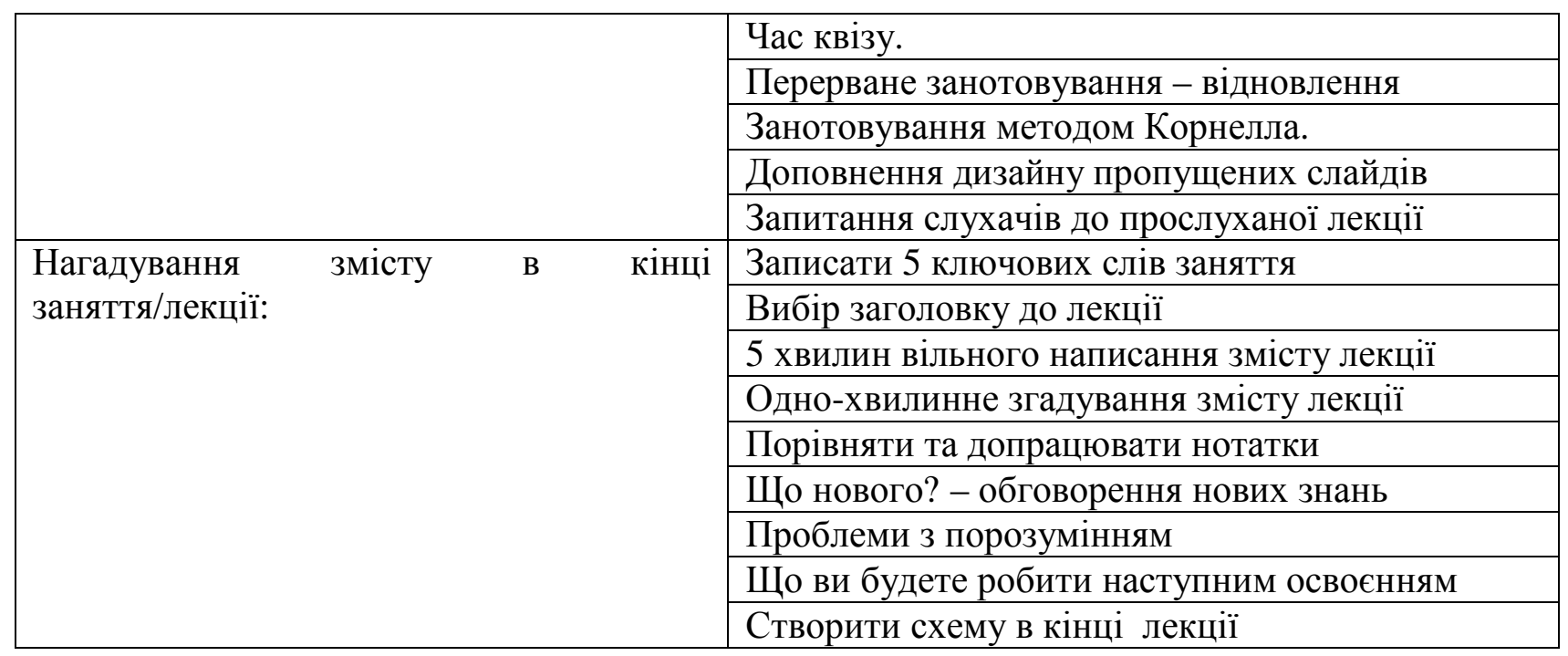

Висновки та напрями подальших досліджень. Курсова підготовка, навчальний процес якої побудований на основі сучасних інтерактивних технологій навчання, забезпечує реалізацію вимог міжнародних організацій у сфері безпеки щодо формування готовності національного персоналу 3С України до участі у МОПМБ.

Активізації навчально-пізнавальному процесу сприяє впровадження в навчальний процес передових розробок та рекомендацій ЕMI, які імплементовані в вищих навчальних закладах Великої Британії.

Дослідження впливу інтерактивних технологій навчання на рівень формування військово-службових компетентностей національного персоналу $є$ перспективою подальших наукових розробок у цьому напрямі.

\section{ЛІТЕРАТУРА}

1. Наказ Міністерства оборони України від 28.01.2016 № 23 "Про затвердження Інструкції з підготовки та застосування національних контингентів, національного персоналу в міжнародних операціях 3 підтримання миру i безпеки". Офіційний вісник України від 04.03.2016 - 2016 р., № 16, стор. 329, стаття 663, код акту 80815/2016.

2. Наказ Міністерства оборони України від 20 липня 2015 року № 346 "Про затвердження Положення про особливості організації освітнього процесу у вищих військових навчальних закладах Міністерства оборони України та військових навчальних підрозділах вищих навчальних закладів України”. Офіційний вісник України від 10.11.2015 2015 р., № 87, стор. 132, стаття 2911, код акта 79163/2015.

3. Закон України від 1 липня 2014 року № 1556-VII “Про вищу освіту". Відомості Верховної Ради, 2014, № 37-38, ст.2004.

4. Информационный центр по вопросам поддержания мира. Учебная подготовка. URL: http://research.un.org/ru/peacekeeping-community/Training (дата звернення: 20.05.2019).

5. BI-SC Collective Training and Exercise Directive (CT\&ED) 075-003. 02 October 2013. 277 p. URL: https://www.act.nato.int/images/stories/structure/jft/bi-sc-75-3_final.pdf (дата звернення: 20.05.2019).

6. Войтех О. В. Підготовка національного персоналу Збройних Сил України до участі в міжнародних операціях з підтримання миру і безпеки як педагогічна проблема. Збірник наукових праць Нац. ун-ту оборони України. 2018. № 1 (37). С. 59-66.

7. “Действия по поддержанию мира" (A4P). URL: https://peacekeeping.un.org/ru/actionfor-peacekeeping-a4p (дата звернення: 20.05.2019). 
8. Вітченко А. О., Осьодло В. І. Педагогіка вищої військової школи: підруч. К.: НУОУ, 2017. 504 c.

9. Вітченко А. О., Осьодло В. І., Салкуцан С. М. Технології навчання у вищій військовій школі: теорія і практика: навч.-метод. посіб. / за заг. ред. В. М. Телелима. К.: НУОУ, 2016. 272 с.

10. Шалигіна Н. Практичні аспекти методики розвитку комунікативної компетентності офіцерів багатонаціональних штабів. Збірник наукових праць “Військова освіта” Нац. ун-ту оборони України. 2018. № 1 (37). С. 305-319.

11. Сисоєва С. О. Інтерактивні технології навчання дорослих: навчально-методичний посібник. НАПН України, Ін-т педагогічної освіти і освіти дорослих. К.: ВД «ЕКМО», 2011. $324 \mathrm{c}$.

12. How effective is English as a medium of instruction (EMI). URL: https://www.britishcouncil.org/voices-magazine/how-effective-english-medium-instruction-emi (дата звернення: 20.05.2019).

13. Качурівський В., Качурівська Г. Застосування Google Forms для моніторингу студентів.

URL: http://ir.lib.vntu.edu.ua/bitstream/handle/123456789/13359/182-184.pdf?sequence=1 ～(дата звернення: 20.05.2019).

14. Kahoot! URL: https://getkahoot.com/ (дата звернення: 20.05.2019).

\section{REFERENCES}

1. Nakaz Ministerstva oborony Ukrayiny vid 28.01.2016 № 23 "Pro zatverdzhennya Instruktsiyi $\mathrm{z}$ pidhotovky ta zastosuvannya natsional $\square$ nykh kontynhentiv, natsional $\square$ noho personalu v mizhnarodnykh operatsiyakh z pidtrymannya myru i bezpeky". [On Approval of the Instructions for the Preparation and Use of National Contingents, National Personnel in International Peacekeeping and Security Operations] registered with the Ministry of Justice of Ukraine on February 10, 2016, No. 206/28336.

2. Nakaz Ministerstva oborony Ukrayiny vid 20 lypnya 2015 roku № 346 "Pro zatverdzhennya Polozhennya pro osoblyvosti orhanizatsiyi osvitn $\square$ oho protsesu u vyshchykh viys $\square$ kovykh navchal $\square$ nykh zakladakh Ministerstva oborony Ukrayiny ta viys $\square$ kovykh navchal $\square$ nykh pidrozdilakh vyshchykh navchal $\square$ nykh zakladiv Ukrayiny". [On Approval of the Provision on the Peculiarities of the Organization of the Educational Process in Higher Military Educational Institutions of the Ministry of Defense of Ukraine and Military Educational Subdivisions of Higher Educational Institutions of Ukraine]. Order of the Ministry of Defense of Ukraine dated July 20, 2015, No. 346. Official Bulletin of Ukraine dated November 10, 2015 2015, No. 87, p. 132, article 2911, code of act 79163/2015.

3. Zakon Ukrayiny vid 1 lypnya 2014 roku № 1556-VII "Pro vyshchu osvitu". [On Higher Education]. Law of Ukraine dated July 1, 2014 № 1556-VII. Information from the Verkhovna Rada, 2014, No. 37-38.

4. Ynformatsyonnyy tsentr po voprosam podderzhanyya myra. Uchebnaya podhotovka. [Information Center for Peacekeeping. Training.] URL: http://research.un.org/en/peacekeepingcommunity/Training (application date: 20.05.2019).

5. BI-SC Collective Training and Exercise Directive (CT\&ED) 075-003. [BI-SC Collective Training and Exercise Directive (CT\&ED) 075-003.] 02 October 2013. 277 p. URL: https://www.act.nato.int/images/stories/structure/jft/bi-sc-75-3_final.pdf (data zvernennya: 20.05.2019).

6. Voytekh O. V. Pidhotovka natsional $\square$ noho personalu Zbroynykh Syl Ukrayiny do uchasti v mizhnarodnykh operatsiyakh z pidtrymannya myru i bezpeky yak pedahohichna problema. (2018) [Voytech O.V. Training of national personnel of the Armed Forces of Ukraine for participation in international peace and security operations as a pedagogical problem.] // Collection of scientific works "Military education" National. Unitary Defense of Ukraine. No. 1 (37). Pp. 59-66. 
7. "Deystvyya po podderzhanyyu myra" (A4P) [Peacekeeping actions (A4P)]. URL: https://peacekeeping.un.org/en/action-for-peacekeeping-a4p (application date: 20.05.2019).

8. Vitchenko A. O., Os $\square$ odlo V. I. Pedahohika vyshchoyi shkoly: pidruch. (2017) [Pedagogy of higher education: underground] - K .: NUOU. 504 p.

9. Vitchenko A. O., Os $\square$ odlo V. I., Salkutsan S. M. (2016). Tekhnolohiyi navchannya u vyshchiy viys $\square$ koviy shkoli: teoriya i praktyka: navch.-metod. posib. [Technologies of studying at a higher military school: theory and practice: teaching method. manual] / for community edit V M Telegram - K .: NUOU. 272 p.

10. Shalyhina N. (2018). Praktychni aspekty metodyky rozvytku komunikatyvnoyi kompetentnosti ofitseriv bahatonatsional $\square$ nykh shtabiv. [Practical aspects of the methodology of the development of the communicative competence of officers of multinational headquarters.] // Collection of scientific works "Military education" National. Unitary Defense of Ukraine. No. 1 (37). Pp. 305-319.

11. Sysoyeva S. O. (2011). Interaktyvni tekhnolohiyi navchannya doroslykh: navchal $\square$ nometodychnyy posibnyk [Interactive adult learning technologies: tutorial] National Academy of Sciences of Ukraine, Institute of Pedagogical Education and Adult Education. K.: VD "EKMO", $324 \mathrm{p}$.

12. How effective is English as a medium of instruction (EMI). URL: https://www.britishcouncil.org/voices-magazine/how-effective-english-medium-instruction-emi (application date: 20.05.2019).

13. Kachurivs $\square$ kyy V., Kachurivs $\square$ ka H. Zastosuvannya Google Forms dlya monitorynhu navchal $\square$ nykh dosyahnen $\square$ studentiv. [Application of Google Forms for monitoring students' academic achievements.] URL: http://ir.lib.vntu.edu.ua/bitstream/handle/123456789/13359/182184.pdf? sequence=1 (application date: 20.05.2019).

14. Kahoot! URL: https://getkahoot.com/ (application date: 20.05.2019)

\section{РЕЗЮМЕ}

Василий Школяренко, кандидат технических наук, старший научный сотрудник

Иван Рудницкий, кандидат технических наук, старший научный сотрудник

Национальный университет обороны Украины имени Ивана Черняховского

\section{Интерактивные технологии обучения как средство повышения эффективности курсовой подготовки национального персонала}

Статья посвящена исследованию состояния разработанности проблематики методического обеспечения формирования военно-служебных компетентностей национального персонала Вооруженных Сил Украины к участию в международных операџиях по поддержанию мира и безопасности на основе внедрения интерактивных технологий обучения в курсовую подготовку. Сформированы требования $к$ подготовке преподавателя при применении интерактивных технологий при организации и проведении основных видов учебных занятий, включая программные средства Google Forms u Kahoot. Предложенные рекомендащии по применению учебных упражнений интерактивных технологий обучения на примере использования передовых разработок и рекомендаций English as Medium of Instruction Оксфордского университета.

Ключевые слова: виды занятий; интерактивные технологии обучения; интерактивные приемы; компетентность; курсовая подготовка; национальный персонал. 


\title{
SUMMARY
}

\author{
Vasyl Shkoliarenko, \\ Candidate of Technical Sciences \\ Ivan Rudnitsky, \\ Candidate of Technical Sciences \\ National University of Defense of Ukraine \\ named after Ivan Chernyakhovskyi
}

\section{Interactive technologies of education as a means of enhancing the efficiency of pre- deployment training of national personnel}

Introduction. The article is devoted to the issue of methodological support in developing professional competencies of the national personnel of the Armed Forces of Ukraine to make them ready for deployment to peacekeeping missions through the introduction of interactive training technologies in pre-deployment courses.

Purpose. To come up with recommendations of the practical implementation of interactive technologies in training courses.

Methods analysis, synthesis, and systematization.

Results. The main results of this research are as follows: the necessity of introduction of interactive training technologies is grounded with regards to the requirements of international security organizations to peacekeeping personnel; the requirements for preparing a teacher to conduct interactive classes are formed; methodological technics in conducting interactive classes are given as examples.

Originality. The novelty of scientific results is the study of the application of the forms and methods of interactive training technologies in the course preparation for the formation of the readiness of the national personnel of the Armed Forces of Ukraine to perform the tasks assigned to them on the basis of a competent approach.

The practical significance of the article is confirmed by the fact that it will allow the implementation of interactive forms and methods in the normative legal acts of peacekeeping activity and teaching materials, used to achieve the competencies of national personnel for participation in peacekeeping missions, which will contribute to the strengthening of international security.

Conclusion. The course training of national personnel of the Armed Forces of Ukraine, the educational process of which is based on modern interactive training technologies, ensures the implementation of the requirements of international security organizations regarding participation in international peace and security operations.

The methodical recommendations for the use of educational technics in interactive training technologies are developed using the experience of conducting classes at British universities.

The study of the impact of interactive training technologies on the level of military and service competencies of national staff is a prospect of further scientific research in this direction.

Key words: forms of classes; interactive learning technologies; interactive technics; competence; course preparation; national staff. 